\title{
Ankündigungen, Termine
}

Veranstalter von Tagungen, Symposien, Workshops etc. sollten ihre Ankündigungen rechtzeitig einreichen. Die Einsendetermine für die einzelnen Hefte des J. Ornithol. sind: für Januar-Heft: 1 . November; April-Heft: 1. Februar; Juli-Heft: 1. Mai; Oktober-Heft: 1. August. Einsendungen bitte möglichst per E-mail oder auf Diskette (DOS-formatiert, WORD).

\section{Second Meeting of the European Ornithologists' Union}

Gdansk/Poland, 15 - 18 September 1999

First Announcement

The European Ornithologists Union was established in 1997. The aim of the Union is the advancement of ornithology and the promotion of the scientific study of birds among ornithologists within Europe.

The first EOU Meeting was held in Bologna, Italy. There was nearly 250 participants from 28 countries (mostly from the west part of Europe). The aim of the Second Meeting is to create an opportunity for a really large number of ornithologists from whole Europe to exchange the most recent results of their work in different topics, to make it possible to discuss different aspects of their research, to make contacts between central/eastern scientists and western ones as effective as possible. Thus it was proposed to hold this conference in Poland to enable many scientists from central and eastern part of Europe to come.

The conference will be held at the University of Gdansk. The venue offers good facilities for meetings, is not far from the centre of the town, easily accessible by car, tram or subway. Gdansk has a good connection with Warsaw both by train and plain, from some countries there are also direct flights to Gdansk Airport (ca. $10 \mathrm{~km}$ from the centre of the town). The detailed information will be given later on.

The conference will include three days of meetings and will consist of plenary sessions, symposia and workshops, and poster sessions with special time for presentation and discussion.

Proceedings will be published.

There will be double rooms at students' hostels (1998 prices per person per day are: $8.5 \mathrm{USD} / \mathrm{first}$ night, 6 USD/following nights). There will be also an offer of rather cheap meals at students' canteen (1998: three meals per day ca. 6 USD), individual subsistence will also be possible. A list of different hotels and more information on them will be enclosed in the Second Announcement. The conference fee will be ca. 120 USD, and it includes conference documents and proceedings. Post-conference excursions will be arranged, free of charge.

For more details contact the Organizing Committee: University of Gdansk, Bird Migration Research Station, Przebendowo, PL-84-210 Choczewo, Poland; phone +48586763220 , fax +4858 67632 65; E-mail: eou.meeting@univ.gda.pl

\section{Avifauna Usbekistans}

Als Mitautor der in russischer Sprache erscheinenden Avifauna von Usbekistan, die in Teilbänden bereits publiziert ist, plane ich eine kommentierte Artenliste der Vögel Usbekistans in deutscher Sprache. Für Hinweise auf altes Sammlungsmaterial, im mitteleuropäischen Bereich publizierte Literatur und vor allem für die Mitteilung neuerer Beobachtungen wäre ich dankbar. Alle Hinweise werden namentlich erwähnt. Edwin Votteler, Rossgasse 15, D-73252 Lenningen. Tel. 07026/3317. 